\title{
Rapid Detection of Grapevine Leafroll-associated virus Type 3 using a reverse transcription loop-mediated amplification (RT-LAMP) method
}

\author{
Helen Ann Walsh ${ }^{\mathrm{a},{ }^{*}}$ Gerhard Pietersen ${ }^{\mathrm{a}, \mathrm{b}}$ \\ a University of Pretoria, Department of Microbiology and Plant Pathology, Pretoria, ${ }^{\mathrm{b}}$ ARC-Plant \\ Protection Research Institute, Queenswood, South Africa
}

*Corresponding author at: Department of Microbiology and Plant Pathology, Nat-ural and Agricultural Sciences Building, University of Pretoria, Lunnon Road, Pretoria0002, South Africa. Tel.: +27 12420 4662.E-mail addresses: u25105958@tuks.co.za, koeksister23@yahoo.co.uk (H.A. Walsh).

\section{Introduction}

Grapevine leafroll disease (GLD) is the most important disease of grapevines, occurring in every grape-growing country (Martelli, 1993). GLD affects grapevines adversely, where it delays the maturation of the berries, decreases the accumulation of sugars and affects the overall yield and quality of the fruit (Over de Linden and Chamberlain, 1970). This negatively impacts on the wine industry, where it affects the quality and colour of the wines, and the table grapes industry, where yields are affected (Golino et al., 2002).

Globally, five serologically distinct, phloem limited viruses designated Grapevine Leafroll-associated viruses (GLRaV) 1-4 and 7, are associated with GLD (Fuchs et al., 2009a; Martelli et al., 2012, 2002) and of these, GLRaV-3 is the most common (Cabaleiro et al., 2007). GLRaV- 3 is part of the Closteroviridae family, where it is type species for the Ampelovirus (Martelli et al., 2002). Studies of the genetic diversity of GLRaV-3 has shown that GLRaV-3 can be separated into five phylogenetic groups(Turturo et al., 2005; Jooste et al., 2010; Gouveia et al., 2011; ). These groups do not seem to be geographically isolated and Group 1 isolates seem to be the most prevalent (Turturo et al., 2005). Initially it was thought that GLRaV-3 was only spread through the use of infected plant propagation material; however it is now known that several species of mealybugs and scale insects act as semipersistent vectors for the virus with varying efficiencies (Cabaleiro and Segura, 1997a; Fuchs et al., 2009a; Golino et al., 2002; Walton, 2004).

GLD is the most important disease of grapevines in South Africa and, as it is the most prevalent virus associated with the disease, GLRaV-3 is considered the most important virus associated with GLD (Pietersen, 2004). A study of the variation of GLRaV-3 isolates in South Africa showed that three genetic variants of GLRaV-3; Group 1, 2 and 3; are present in South African Vineyards (Jooste et al., 2011). Several insects are known to vector the virus in South Africa, however the mealybug Planococcus ficus is considered the most important (Douglas and Krüger, 2008).

GLD occurs in all grape varieties, however symptom expression can vary greatly (Over de Linden and Chamberlain, 1970). In red wine cultivars, symptoms are usually expressed as interveinal reddening and down rolling of the leaves and are 
most distinct in autumn. However white wine cultivars tend to be asymptomatic (with the exception of a few varieties). GLD is usually also symptomless in most American wild Vitis sp. used as rootstocks and their hybrids (Krake et al., 1999). This variation in symptoms complicates control of the disease as asymptomatic infected individuals can only be detected using either serological (e.g. ELISA) or molecular (e.g. PCR) methods before they can be removed.

In 2002, a study was conducted at a commercial wine farm to prove that GLD could be controlled using an integrated control strategy (Pietersen et al., 2013). The strategy involved the planting of certified material, control of the vector through the use of systemic insecticide and the removal of infected vine material by rogueing (Pietersen and Walsh, 2012; Pietersen et al., 2013). This has been shown to be highly effective for the control of GLD in red cultivars, where symptomatic plants are identified on a vine- for- vine basis at the beginning of autumn each year (Pietersen and Walsh, 2012; Pietersen et al., 2013). However in white cultivars control is more problematic, due to the lack of symptom expression in the majority of varieties.

Currently each season infected white cultivars are identified using Enzyme-linked immunosorbent assay (ELISA) (Ling et al., 2000) before rogueing (Pietersen et al., 2013; Pietersen and Walsh, 2012). ELISA tests are (usually) performed by cell technicians on the wine farms which have basic facilities such as water baths and fridges but do not have specialised equipment (e.g thermocyclers) which makes diagnostic test such as RT-PCR unfeasible. ELISA technique is simple and inexpensive (as it requires very little equipment) and can be used for a large number of samples. However, it is less sensitive than molecular techniques (Arora et al., 2006) and is time consuming. Reverse transcriptase polymerase chain reaction (RTPCR) is sensitive and is less time intensive than ELISA but requires specialised equipment and is more complex than ELISA, usually being performed by trained technicians. The ideal detection technique needs to simple, rapid and specific and would ideally give results in real-time but would not require specialised equipment.

Loop-mediated Amplification of Nucleic acid (LAMP), a rapid, specific simple means of amplifying nucleic acid, has emerged as a powerful diagnostic technique. (Parida et al., 2008). LAMP relies on the a strand displacing DNA polymerase in conjunction with 4 primers (which target 6 specific areas on the target) to amplify target nucleic acid under isothermal conditions within a short period of time (Notomi et al., 2000).

LAMP can be monitored in a number of ways; LAMP amplicons can be viewed using gel electrophoresis; through visual inspection by inspecting turbidity (Mori et al., 2001), colourimetric indicators (Goto et al., 2009; Iwamoto et al., 2003) or intercalating dyes (Maeda et al., 2005).

LAMP has shown to be a highly versatile diagnostic technique and has been used in the detection of a wide variety of pathogens (Parida et al., 2008). There are a number of advantages associated with LAMP; it is isothermal so does not require specialised thermocycling equipment and tests can be heated in a simple heating block or a water bath. The system is highly efficient with no time lost for cycling between temperatures. Secondly because it requires at least 4 primers, it is highly specific. LAMP has also been shown to be more robust than other molecular based 
techniques and is less affected by biological substances which have been shown to be inhibitory in other techniques (Francois et al., 2011)

This paper reports on the development of a rapid detection technique for GLRaV-3 through the combination of a crude nucleic acid extraction protocol with RT-LAMP and colourimetric assay. This technique has been shown to be rapid, efficient and can reduce the time needed to test a sample from two days by ELISA to two hours with sensitivity comparable to that of nested RT-PCR. This technique may provide an alternative to ELISA and contribute the control of GLD in white cultivars.

\section{Materials and Methods}

\section{Plant Material and Nucleic Acid}

Petioles were collected from grapevines infected with GLRaV-3 kept in the glasshouses at the University of Pretoria Experimental Farm, Pretoria (01-2839, 010257, 01-2639); as well as from the glasshouses at the Agricultural Research Centre (ARC) Plant Protection Research Institute (PPRI), Roodeplaat (623, 621, PL-20, GH 30, 74/2/56, 37/71/84, 74/02/02, 93/0904/ 74/7/56, 92/1027/ 74/2/56). Bark scrapings infected with GLRaV-3 were obtained from dormant material from PPRI $(623,621$, PL-20). GLRaV-3 strain PL-20 plasmids (pGEM plasmid, Promega) containing the target area (nucleotide positions 5876-8286 on PL-20 genome GQ352633) for the LAMP primers (designated F1, F8 and F9 ) were obtained from Elize Jooste at the PPRI (Jooste et al., 2010), and were used to assess the LAMP reaction, separately from the reverse transcriptase step.

\section{LAMP Primer Design}

Primers for LAMP on GLRaV-3 were designed using the 6 available GLRaV-3 whole genomes; GP18 (EU259806) (Maree et al., 2008), 621, 623, PL-20 (GQ352631, GQ352632 and GQ352633) (Jooste et al., 2010), Cl- 766 (EU344893) (Engel et al., 2008) and NY-1 (AF037268) (Ling et al. 1998). The genomes were aligned ClustalW in Bioedit (Version 7.0.8, Ibis Bioscience, Carlsbad) and areas with high similarity (> $90 \%$ ) were used as targets. The gene region for RdRp (RNA dependent RNA polymerase) was found to have the highest similarity and was used to design primers. LAMP primers were then designed using using Primer Explore V4 (http://primerexplorer.jp/elamp4.0.0/index.html). Possible primers were then compared to available GLRaV-3 genomes (as well as GenBank database) using BLAST (http://blast.ncbi.nlm.nih.gov/Blast.cgi) and primers with greatest specificity were selected (> 98\% homology for all primers) (Table ) and synthesised by IDT (lowa, USA) 
Table 1: Sequences of GLRaV-3 specific RT-LAMP primers

\begin{tabular}{|c|c|c|c|}
\hline $\begin{array}{l}\text { Primer } \\
\text { Name }\end{array}$ & Type & Position ${ }^{1}$ & Sequence (5'-3') \\
\hline F3 & $\begin{array}{l}\text { Forward Outer } \\
\text { Primer }\end{array}$ & $7728-7747$ & GAAGTGTAACCTCGTCACGT \\
\hline B3 & $\begin{array}{l}\text { Backward Outer } \\
\text { Primer }\end{array}$ & $7941-7958$ & GCCCGCTTGAGAGACTTG \\
\hline FIP & $\begin{array}{l}\text { Forward Inner } \\
\text { Primer } \\
\text { (F1c-TTTT- F2) }\end{array}$ & $\begin{array}{l}\text { F1c: } 7793-7813 \\
\text { F2: } 7752-7771\end{array}$ & $\begin{array}{l}\text { CATGCGCCACAGAGTCGTCACTTTT- } \\
\text { AAATGGGAATTTCAACGCCG }\end{array}$ \\
\hline BIP & $\begin{array}{l}\text { Backward Inner } \\
\text { Primer } \\
\text { (B1c- TTTT-B2) }\end{array}$ & $\begin{array}{l}\text { B1c: } 7851-7871 \\
\text { B2: } 7909-7928\end{array}$ & $\begin{array}{l}\text { GCTCGTTTAGCAGAGGTGACGGTTTT- } \\
\text { GCCCTTTTGTCCAACCAATC }\end{array}$ \\
\hline
\end{tabular}

* Genome position according to GLRaV-3 strain 621 complete genome sequence (GenBank accession number GQ352631)

\section{$R T$-LAMP}

The final LAMP reaction mixture (25ul total volume in a $0.2 \mathrm{ml}$ tube) was made up as

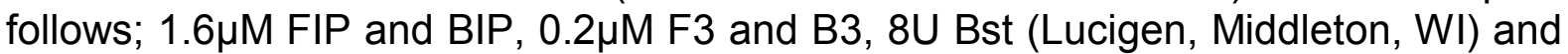

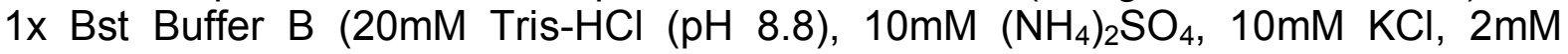
$\mathrm{MgSO}_{4}$ and $0.1 \%$ Triton $\mathrm{X}-100$ ) (Lucigen), $1 \mathrm{M}$ Betaine (Sigma- Aldrich, St Louis, MO, USA), $1.4 \mathrm{mM}$ dNTPs (Promega, Madison, WI USA), $7 \mathrm{mM} \mathrm{MgCl} 2$ (Fermentas,

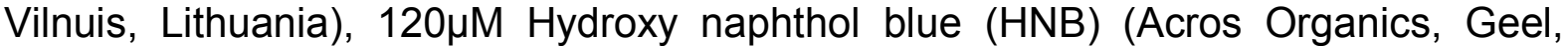
Belgium), 10U AMV reverse transcriptase (Roche, Palo Alto, CA USA) and $2 \mu \mathrm{l}$ of RNA. The mixture was then incubated at $60^{\circ} \mathrm{C}$ using a heating block (Eppendorf Thermostat Plus 3130, Hamburg, Germany) for 1 hour followed by heating to $80^{\circ} \mathrm{C}$ for 10 minutes to terminate the reaction. Results were analysed by a visual comparison of the colour change of samples to a either a healthy control or a negative (water) control. In order to prevent contamination LAMP mixtures were prepared in a separate laboratory from sample processing and post- LAMP visualisation.

\section{Optimisation of LAMP}

The LAMP reactions were optimized by assessing different incubation temperatures as well as the concentration and ratio of inner: outer primers and $\mathrm{Mg}^{2+}(4 \mathrm{mM}-$ $10 \mathrm{mM}$ ). The temperature optimisation (using the optimum primer concentration) was carried out $60,61,62,63,64$ and $65^{\circ} \mathrm{C}$ for 1 hour and results were analysed using turbidity and confirmed using $2 \%$ agarose gel electrophoresis. All the optimisation reactions included negative controls; where no DNA template was present (water control) and the pGEM plasmid without the target region insert.

\section{Visualisation of LAMP products}

Products of LAMP were visualised using three different methods: 1) agarose gel electrophoresis where $5 \mu \mathrm{l}$ of sample was loaded per well of a $2 \%$ Agarose gel prestained with ethidium bromide at $5 \mathrm{ug} / \mathrm{ml}$ and electrophoresed for $35 \mathrm{~min}$ at $100 \mathrm{~V}$ in 1 $x$ TAE buffer (40mM Tris-acetate, $1 \mathrm{mM}$ EDTA, $\mathrm{pH} 8.2$ ). Results were viewed using a UV-transilluminator (310nm) , A wide-range molecular weight DNA marker (100-bp 
ladder) (Inqaba Biotechnological Industries, South Africa) was used on each gel as the standard; 2) Turbidity; where the turbidity of positive samples were visually compared with two negative controls which contained either no template or pGEM plasmid without the target region. These LAMP reactions were also centrifuged for 5 minutes at 10 000g (Eppendorf 5804 centrifuge, Hamburg Germany) and each tube examined for a white pellet; and 3) the addition of HNB, prepared according to Goto et al. (2009), with the results visually analysed through comparison of the samples to the negative control. HNB results were initially confirmed using $2 \%$ agarose gel electrophoresis.

\section{Crude RNA extraction}

Several methods were evaluated to select a reliable procedure to prepare crude RNA. For each method petioles were selected from a sample with a high viral titre (01-0257), a sample with a low viral titre (01-2639), and a healthy negative control (01-2839) were included.

The optimal method assessed was; extraction $0.2 \mathrm{~g}$ of sample homogenized in $5 \mathrm{ml}$ of extraction buffer (PBS, pH 7.2, supplemented with $2 \%(\mathrm{w} / \mathrm{v})$ polyvinylpyrrolidone (PVP-10) and $0.2 \%$ (w/v) sodium diethyl dithiocarbamate) (Bertolini et al., 2001) in filter separated plastic bags (Bioreba, Reinach Switzerland), using a Homex 6 homogenizer (Bioreba), 30 $\mathrm{\mu l}$ of this sample was added to nitrocellulose membrane (Sigma-Aldrich) which was dried for between 30 minutes. A $3 \mathrm{~mm}^{2}$ disc was punched out using paper punch (Roche, Germany) which was added to $100 \mu$ l of GES buffer (Osman and Rowhani 2006) and incubated at $95^{\circ} \mathrm{C}$ for 10 minutes. $2 \mu \mathrm{l}$ of extract was added to RT-LAMP. This method gave the most reliable results and was used in all further testing.

Other methods tested included ; 1) the print capture procedure according to La Notte (1997), and several methods of RNA extraction including; 2) a simple extraction in an alkaline buffer (50mM NaOH, 2.5mM EDTA) (Turturo et al., 1998) according to Singh et al. (2006); 3) viral immobilization on nylon membrane using extraction buffer (Osman and Rowhani, 2006); 4) use of petioles used instead of midrib tissue in a modification of the method of Habili et al. (1997) ; 5) extraction of $0.5 \mathrm{~g}$ of sample, ground in extraction buffer $(50 \mathrm{mM}$ EDTA, $100 \mathrm{mM}$ Tris- $\mathrm{HCl}, 500 \mathrm{mM}$ $\mathrm{NaCl}$ and $10 \mathrm{mM} \beta$-mercaptoethanol) (Al-Musa et al., 2008); 6) maceration of $0.5 \mathrm{~g}$ of sample in GES buffer (Osman and Rowhani 2006); and 7) grinding of $1 \mathrm{~g}$ of sample in grapevine ELISA extraction buffer $\left(0.1 \mathrm{M}\right.$ Tris- $\mathrm{HCl} \mathrm{pH} 7.6,0.01 \mathrm{M} \mathrm{MgSO}_{4}, 4 \%$ polyvinylpolypyrrolidone (PvPP (insoluble), 0.2\% ß-Mercapto-ethanol (ME), 2\% Triton - X100) (Ling et al., 2001) after which it was centrifuged (Eppendorf) for 5 minutes at $10000 \mathrm{~g}$ and $1 \mu \mathrm{l}$ of sample was added directly to the RT-LAMP.

\section{Pooling of Samples}

LAMP samples were pooled by processing individual samples according to the optimal method above and pooling $10 \mu \mathrm{l}$ of each GES extract. Alternative methods tested included; pooling petioles by combining 6 petioles from each sample and adding $0.2 \mathrm{~g}$ of combined petioles to Extraction buffer and; pooling extracted plant saps (100ul of plant in extraction buffer) before adding to $30 \mathrm{ul}$ of combined saps to nitrocelluose membrane. Pooling of GES extracts had greatest consistency (results not shown) and was used for all further testing. 
In order to pool the samples being tested in parallel with ELISA, these were processed according to ELISA protocol and 100ul of each sample was pooled together for use in LAMP.

\section{Nested PCR}

Nested PCR was carried out according to Ling et al. (2001) on

petioles collected and macerated in liquid nitrogen, after which $0.1 \mathrm{~g}$ of each sample was suspended in grapevine ELISA extraction buffer (Ling et al., 2001).

A PCR reaction mixture (to a total volume of $50 \mathrm{ul}$ in $0.2 \mathrm{ml}$ tubes) (2\% Triton $\mathrm{X}-100$, 1x $\mathrm{NH}_{4}$ Biotaq buffer (Bioline, London England), 3.5mM dNTP (promega), $1 \mu \mathrm{M}$ each of primer 93-110 and 92-98 (IDT) (Ling et al., 2001) 10mM dithiothreitol (DTT) (Sigma-Aldrich), $1.5 \mathrm{mM} \mathrm{MgCl}_{2}$ (Fermentas), $18 \mathrm{U}$ Protector RNase inhibitor (Roche), $8 \mathrm{U}$ Avian myeloblastis virus (AMV) reverse transcriptase (Roche) and 0.5U Biotaq DNA polymerase (Bioline)) and $0.5 \mu$ l of crude RNA extract was made up. A healthy plant control (Black spanish) and a water (no template control) were included for all $\mathrm{PCR}$ tests. The reaction temperature profile was of reverse transcription at $37^{\circ} \mathrm{C}$ for $45 \mathrm{~min}$; denaturation at $94^{\circ} \mathrm{C}$ for $2 \mathrm{~min} ; 35$ cycles of $94^{\circ} \mathrm{C}$ for $60 \mathrm{sec}, 50^{\circ} \mathrm{C}$ for $1 \mathrm{~min}$, $72^{\circ} \mathrm{C}$ for $2 \mathrm{~min}$, and a final elongation step of $72^{\circ} \mathrm{C}$ for $10 \mathrm{~min}$ using a Biorad ( Hercules, California) T100 TM thermocycler.

The product of the first round RT- PCR $(0.5 \mu \mathrm{l})$ was added to $50 \mu \mathrm{l}$ of PCR reaction mixture $\left(1 \times\right.$ Biotaq $\mathrm{NH}_{4}$ buffer (Bioline); $175 \mu \mathrm{M}$ dNTP ((Promega), $1 \mu \mathrm{M}$ primer 9323, $1 \mu \mathrm{M}$ primer 93-40 (IDT), $1.5 \mathrm{mM} \mathrm{MgCl}_{2}$ (Fermentas, Vilnuis, Lithuania) and 0.5U Biotaq (Bioline)). The cycling profile was denaturation at $94^{\circ} \mathrm{C}$ for $2 \mathrm{~min} ; 30$ cycles of $94^{\circ} \mathrm{C}$ for $1 \mathrm{~min}, 50^{\circ} \mathrm{C}$ for $1 \mathrm{~min}, 72^{\circ} \mathrm{C}$ for $2 \mathrm{~min}$ and a final elongation of $72^{\circ} \mathrm{C}$ for $10 \mathrm{~min}$. Products of the reaction were analysed by electrophoresis as above.

\section{ELISA}

Six petioles were collected from each vine and extracted at a 1/10 (weight / volume) ratio in ELISA extraction buffer $\left(0.1 \mathrm{M}\right.$ Tris/ $\mathrm{HCl}, \mathrm{pH} 7.6$ buffer with $0.01 \mathrm{M} \mathrm{MgSO}_{4}, 4 \%$ PVPP, and $2 \%$ Triton $\mathrm{X}-100$ ) in filter separated plastic bags (Bioreba), using a Homex 6 homogenizer (Bioreba AG, Switzerland). A triple antibody sandwich (TAS) ELISA, capable of detecting grapevine leafroll associated virus 1 (GLRaV-1), -2 (GLRaV-2) and GLRaV-3 separately or simultaneously (Goszczynski et al., 1997, 1996; Goszczyński et al., 1995) was then used to detect GLRaV-3. A Healthy Control (Black Spanish) and a buffer control were included as negative controls and a known positive extract (623) was included as a positive control. Virus specific antibodies, developed using electrophoretically-separated coat proteins of the respective viruses (Goszczynski et al. 1996, 1997, 1998) were used. Commercial goat-anti-rabbit antibodies conjugated with alkaline phosphatase (Sigma-Aldrich, St. Louis, MO, USA) was used for sero-reaction detection. Positive results were detected as those individuals that yielded an absorbance value $(405 \mathrm{~nm})$ of 0.122 . In the case of sensitivity testing of ELISA, vines were pooled into groups of $10,20,30$ and 50 respectively. The average absorbance of healthy control plants plus three standard deviations was used as a positive/negative threshold for ELISA. 


\section{Results}

\section{LAMP}

In the initial tests on GLRaV-3 specific primers. LAMP was tested against plasmids containing GLRaV-3 inserts of the target area (F2, F8 and F9) as well as a plasmid without the target region and a negative control where water was added in place of template. The LAMP products were analysed using $2 \%$ agarose gel electrophoresis. LAMP amplified the target in all three plasmids, with typical ladder-like pattern displayed for all positive samples (Figure 10) while no amplification was observed in either of the negative controls. The ladder-like pattern is due to the formation of stem-loop concantenate products (of varying sizes) produced by LAMP.

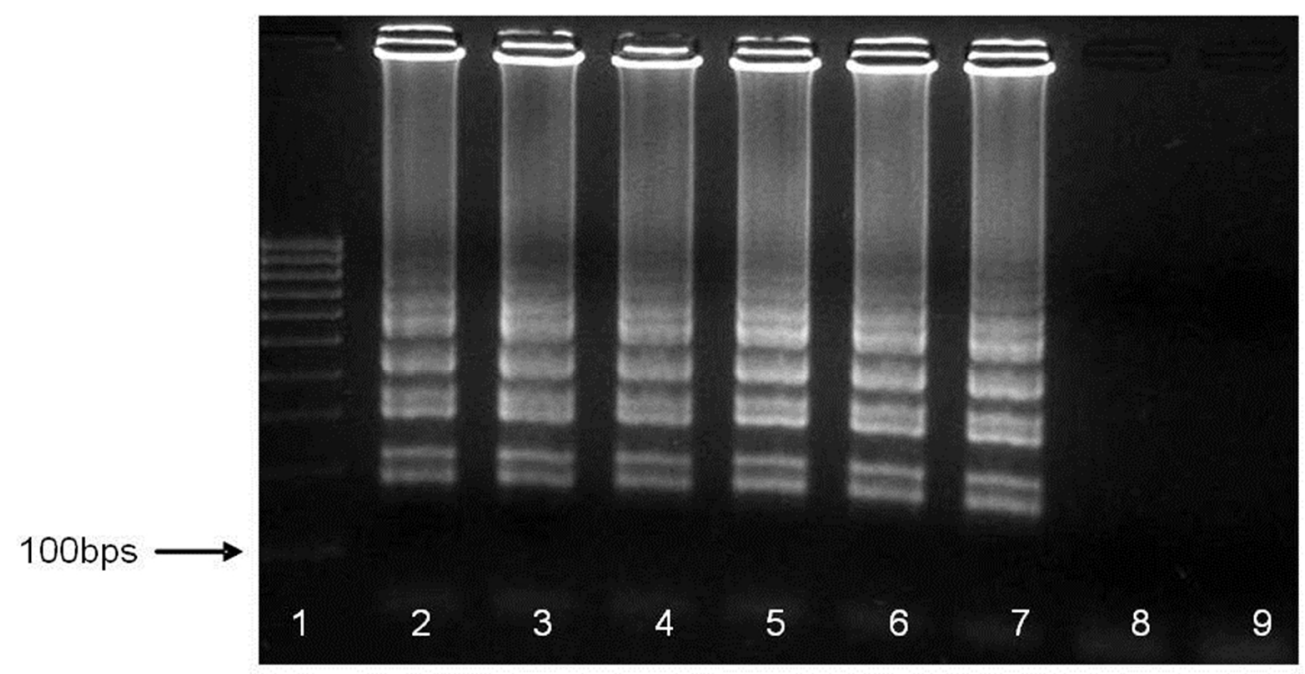

Figure 1: LAMP on plasmids containing target area of GLRaV-3. Lane 1:

Molecular marker (100bp ladder); Lane 2-3: Plasmid F2; Lane 4-5: Plasmid F8; Lane 6-7: Plasmid F9; Lane 8: Negative control: Plasmid only; Lane 9: Negative control: Water.

\section{Optimisation of LAMP}

Plasmid F2, F8 and F9 were used for the optimisation of the LAMP system. The relative detection limit for LAMP (under the conditions of Notomi et al, 2000) was determined using dilutions of plasmids F2, F8 and F9 at 1:200, 1:500, 1:1000, 1:2000, 1:5000 and 1:10 000. Each dilution was tested in triplicate and positive controls were included of each clone at a dilution of 1:100. Negative controls, where template was substituted for water or non-transformed plasmid, were also used. The relative detection limit of LAMP was established at 1:2000 after which LAMP was optimised for use with GLRaV-3 specific primers.

The concentration and the ratio of inner: outer primers was optimised by varying the concentration of outer primer $(0.1 \mu \mathrm{M}-0.5 \mu \mathrm{M})$ and the ratio of outer: inner primer to $1: 4,1: 6,1: 8$, and 1:10. At each variation, LAMP was run against clones F2, F8 and F9 diluted at 1:2000, 1:5000 and 1:10 000 and results were analysed using turbidity and confirmed using agarose gel electrophoresis. Results of the manipulation showed that where the concentration of outer primers is at $0.2 \mu \mathrm{M}$ or above and the ratio of inner: outer primer is 1:8 or higher, the sensitivity of LAMP sensitivity increased to detect plasmid diluted to 1:5000. 
In order to determine of the optimal temperature, LAMP reactions were incubated at $60,61,62,63,64$ and $65^{\circ} \mathrm{C}$ (range selected because of primer constraints) for 60 min and efficiency was monitored by determining the percentage increase in DNA concentration $(\mathrm{ng} / \mathrm{\mu l})$ from before and after amplification in 1 hour using a Nanodrop as a increase in the amount of product will lead to an increase in the amount of magnesium pyrophosphate produced. Results of the temperature optimisation showed that LAMP performs at similar levels between 60- 62 and performs optimally at $63^{\circ} \mathrm{C}$ (Table 2: Results of optimisation of temperature for incubation of LAMP). However as AMV has a maximum temperature $60^{\circ} \mathrm{C}$, and the difference between performance between 60 and $63^{\circ} \mathrm{C}$ is not that different, LAMP reactions were routinely incubated at $60^{\circ} \mathrm{C}$.

$\mathrm{Mg}^{2+}$ concentration was varied between $4 \mathrm{mM}$ and $10 \mathrm{mM}$. While a positive control of $6 \mathrm{mM}$ was included. Results were analysed using turbidity and confirmed using gel electrophoresis. The results showed that a minimum $\mathrm{Mg}^{2+}$ concentration of $5 \mathrm{mM}$ is required for LAMP reaction to take place and that LAMP performs optimally at $\mathrm{Mg}^{2+}$ concentration of $7 \mathrm{mM}$. At $9 \mathrm{mM}$ and above amplification either decreased $(9 \mathrm{mM})$ or no amplification was observed $(10 \mathrm{mM})$.

Table 2: Results of optimisation of temperature for incubation of LAMP

\begin{tabular}{|l|l|l|l|}
\hline Temperature & $\begin{array}{l}\text { DNA concentration } \\
\text { Before amplification } \\
(\mathrm{ng} / \mathrm{ul})\end{array}$ & $\begin{array}{l}\text { DNA concentration after } \\
\text { amplification(ng/ul) }\end{array}$ & $\begin{array}{l}\text { Average } \\
\text { Percentage } \\
\text { increase }\end{array}$ \\
\hline 60 & 153.67 & 2769.3 & 90.57 \\
\hline 61 & 242.57 & 3838.76 & 86.78 \\
\hline 62 & 241.67 & 2763.6 & 88.93 \\
\hline 63 & 100.7 & 3176.33 & 94.19 \\
\hline 64 & 524.4 & 3390.6 & 76.97 \\
\hline 65 & 119.93 & 3833.83 & 93.74 \\
\hline
\end{tabular}

\section{Visualisation of LAMP products}

LAMP product were initially visualised using agarose gel electrophoresis (Error! Reference source not found.B ), however this method was laborious and contributed to a large amount of contamination. Positive results were then judged based on either turbidity (Error! Reference source not found. C) or colourimetrically (Error! Reference source not found.A) using HNB. In the case of turbidity, tubes became visually turbid and a white precipitate formed at the bottom of the reaction tube when the tubes were centrifuged only where

amplification occurred. This was confirmed using agarose gel electrophoresis.

To test HNB, clones F2, F8 and F9 were amplified in LAMP reaction containing HNB (Goto et al., 2009) and tubes were visually monitored for a colour change from violet to sky blue. Positive results were seen for all clones, with an easily discernible colour change from violet to sky blue. Neither negative control (untransformed plasmid and water) displayed any colour change, showing that the colour change is specific to positive samples. HNB results were the most easily discernible and HNB was used as indicator in all further tests. 


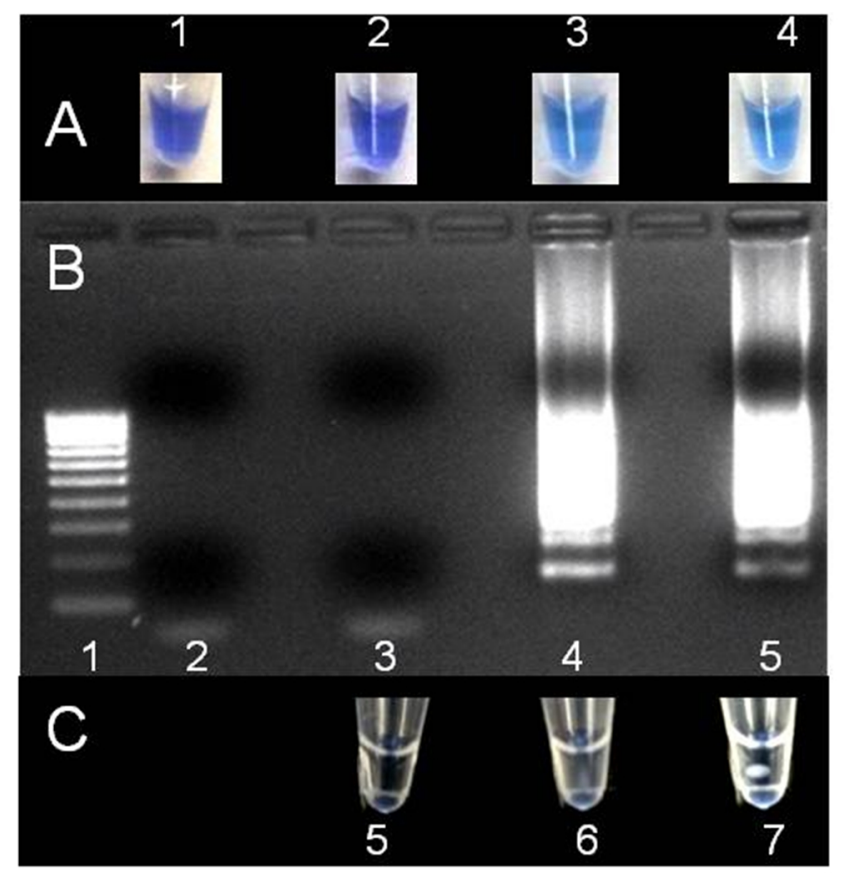

Figure 2: Examples of the three visualisation methods tested for monitoring LAMP. A) visualisation of LAMP product using HNB. Tube 1,2: Negative Control HNB reactions (Untransformed plasmid, water respectively) (Violet); Tube 3,4: Clone F2 (Positive HNB reaction) (Blue). B) visualisation of LAMP product using agarose gel electrophoresis. Lane 1: Ladder (100bps); Lane 2, 3: Negative Controls (Untransformed Plasmid, water control respectively); Lane 4, 5: Clone F2. C) visualisation of LAMP product using turbidity. Tube 5: Negative Control Turbidity reaction (clear); Tube 6: Clone F2 (Positive Turbidity reaction); Tube 7: Clone F2 (Positive Turbidity reaction, precipitate).

\section{$R T$-LAMP}

RNA was extracted from Bark scrapings of three different GLRaV-3 strains infected grapevines (623, 621 and PL-20). RNA was added to RT-LAMP reaction and incubated for 1 hour. Results were judged based on the colour change of HNB from violet to sky blue. A positive control (11-3014) and a healthy plant control (01-2839) were included. All samples, known to be positive for GLRaV-3 displayed the desired colour change from Violet to Sky blue while the negative controls remained Violet (

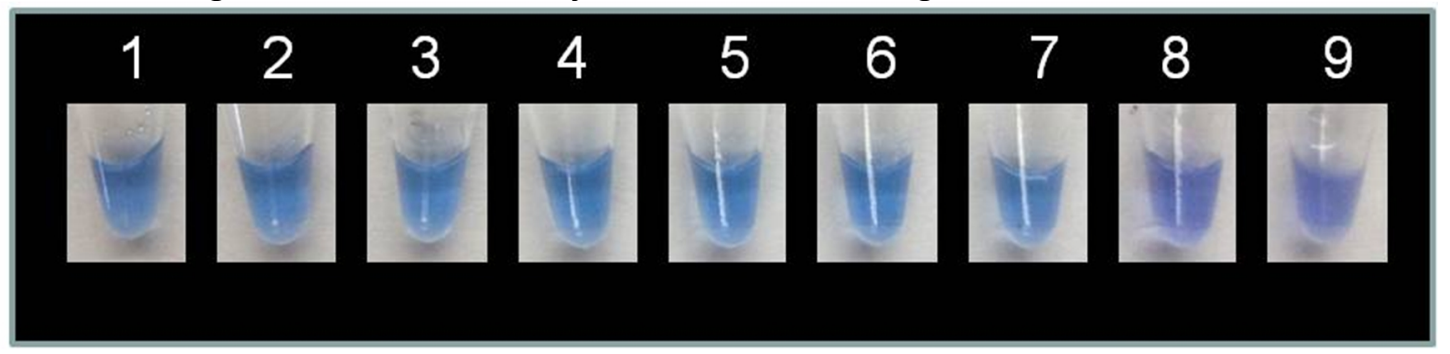

Figure 3). 


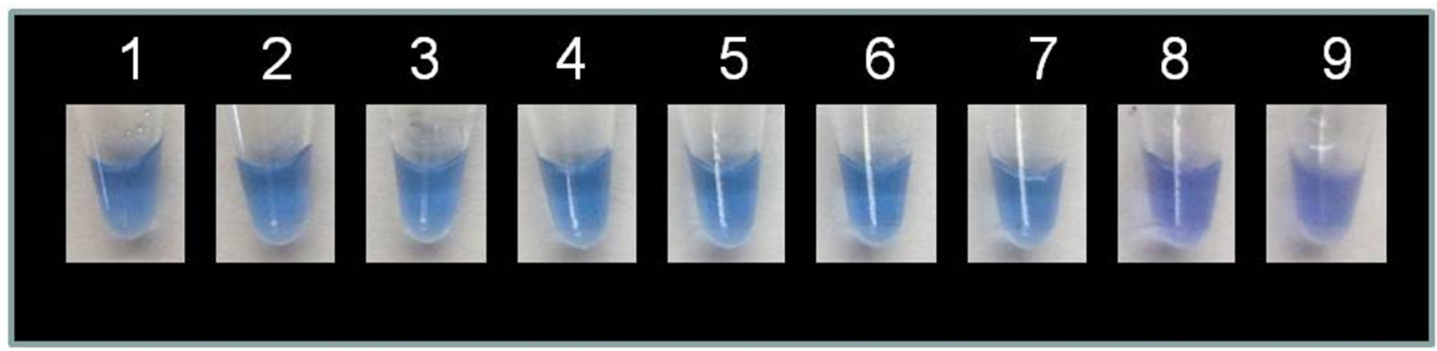

Figure 3: HNB reaction following RT-LAMP on three GLRaV-3 strains. Tube 1-2 PL-20; Tube 34 621; Tube 5-6 623; Tube 7: Positive Control (01-3014); Tube 8: Healthy plant (01/2839); Control Tube 9: Negative control (water)

\section{Crude extraction protocol}

Several crude nucleic acid extraction protocols were evaluated for use with GLRaV-3 specific RT-LAMP. In each protocol a sample with a high viral titre and low viral titre were tested to ensure the sensitivity of the protocol. No amplification was observed when using the print capture method (1) (La Notte, 1997) or RNA extraction protocols (2), (4), (5). Further, the addition of extraction buffers (2) and (4) caused the HNB indicator to change to sky blue before incubation without any amplification of nucleic acid occurring. Protocol (3) amplified sample 01-2857, however was not able to amplify sample 01-2639. Using the ELISA extraction buffer (protocol (7)), RTLAMP detected both the strong and the weak positive when RT-LAMP was evaluated using turbidity. However, the PVPP in the buffer caused the HNB to precipitate out of the reaction and therefore this buffer cannot be used where HNB is used as the means of evaluating RT-LAMP reaction. The optimal method was found to be where virus was immobilised on nitrocellulose membrane and then released using GES buffer was shown to be the most reliable protocol for detecting GLRaV-3, with no cross reaction with the HNB. This protocol (1) was used in all further testing of the samples.

\section{Comparison of ELISA, Nested PCR and LAMP}

In order to ensure that RT-LAMP could detect GLRaV-3 as reliably as ELISA and Nested PCR, petioles were collected from the same 10 grapevines infected with GLRaV-3 and were tested using ELISA, Nested PCR and RT-LAMP. The samples represented the major phylogenetic groups of GLRaV-3 present in South Africa; Group 1, 2, 3 (Jooste et al., 2011) as well as Group 6. All 10 samples were detected using RT-LAMP, ELISA and Nested PCR (

Table ).

Table 3: Results of ELISA, RT-PCR and RT-LAMP on GLRaV-3 infected grapevines

\begin{tabular}{|l|l|l|l|l|}
\hline & ELISA & & RT-LAMP & Nested PCR \\
\hline Sample & OD \pm & SD & & \\
\hline 623 & 0.239 & 0.038 & + & + \\
\hline GH 30 & 2.403 & 0.134 & + & + \\
\hline PL-20 & 1.790 & 0.080 & + & + \\
\hline $74 / 2 / 56$ & 1.269 & 0.122 & + & + \\
\hline $37 / 71 / 84$ & 1.113 & 0.044 & + & + \\
\hline $74 / 02 / 02$ & 2.308 & 0.187 & + & + \\
\hline 621 & 0.960 & 0.092 & + & + \\
\hline $93 / 0944$ & 2.155 & 0.066 & + & + \\
\hline
\end{tabular}




\begin{tabular}{|l|l|l|l|l|}
\hline $74 / 7 / 58$ & 2.496 & 0.148 & + & + \\
\hline $92 / 1027$ & 0.485 & 0.043 & + & + \\
\hline $\begin{array}{l}\text { Healthy Control } \\
\text { (Black Spanish) }\end{array}$ & 0.068 & 0.002 & - & - \\
\hline
\end{tabular}

\pm - Average of two repetitions using three ELISA wells per assay; SD: Standard Deviation. A sample was considered positive if the OD $(405 \mathrm{~nm})$ measured after $1 \mathrm{~h}$ substrate incubation, was higher than 0.072 (Healthy Control O.D + 3*SD)

+ - Positive reaction (in both replicates) of two repetitions of RT-LAMP/ Nested PCR

Once it had been established that RT-LAMP could be used to detect the same diversity of GLRaV-3 as ELISA and Nested- PCR the sensitivity of the three techniques relative to one another of the was compared. Three samples $(623,621$ and PL-20) were selected and were pooled with healthy samples at 1:1 (1 infected plant: 1 Healthy Plant), 1:10, 1:20, 1:50, 1:60 and 1:100 ratio. The detection limit of each test was the point where the test could no longer detect all three samples. The detection limit of ELISA was found to be at a ratio of 1:30 infected plants (Table), the detection limit of nested PCR (Figure 4) and RT-LAMP was found to be a ratio of 1: 50 infected plants. Based on these results, RT-LAMP has a comparably sensitivity to Nested PCR and both molecular techniques are more sensitive than ELISA.

Table 4: Results of sensitivity testing of ELISA for comparison with RT-LAMP and nested PCR

\begin{tabular}{|l|l|l|l|l|}
\hline Sample & $1: 10 \pm S D$ & $1: 20 \pm S D$ & $1: 30 \pm S D$ & $1: 50 \pm S D$ \\
\hline PL-20 & $0.81 \pm 0.03$ & $0.54 \pm 0.04$ & $0.34 \pm 0.04$ & $0.10 \pm 0.1$ \\
\hline 623 & $1.17 \pm 0.05$ & $0.86 \pm 0.0 .2$ & $0.47 \pm 0.04$ & $0.11 \pm 0.00$ \\
\hline 621 & $0.62 \pm 0.03$ & $0.46 \pm 0.03$ & $0.24 \pm 0.05$ & $0.12 \pm 0.01$ \\
\hline $\begin{array}{l}\text { Healthy Control } \\
\text { (Black Spanish) }\end{array}$ & $0.078 \pm 0.01$ & & & \\
\hline
\end{tabular}

\pm - Average of two repetitions using three ELISA wells per assay; SD: Standard deviation. A sample was considered positive if the OD $(405 \mathrm{~nm})$ measured after $1 \mathrm{~h}$ substrate incubation, was higher than 0.12 (Healthy Control O.D + $3^{*} \mathrm{SD}$ )

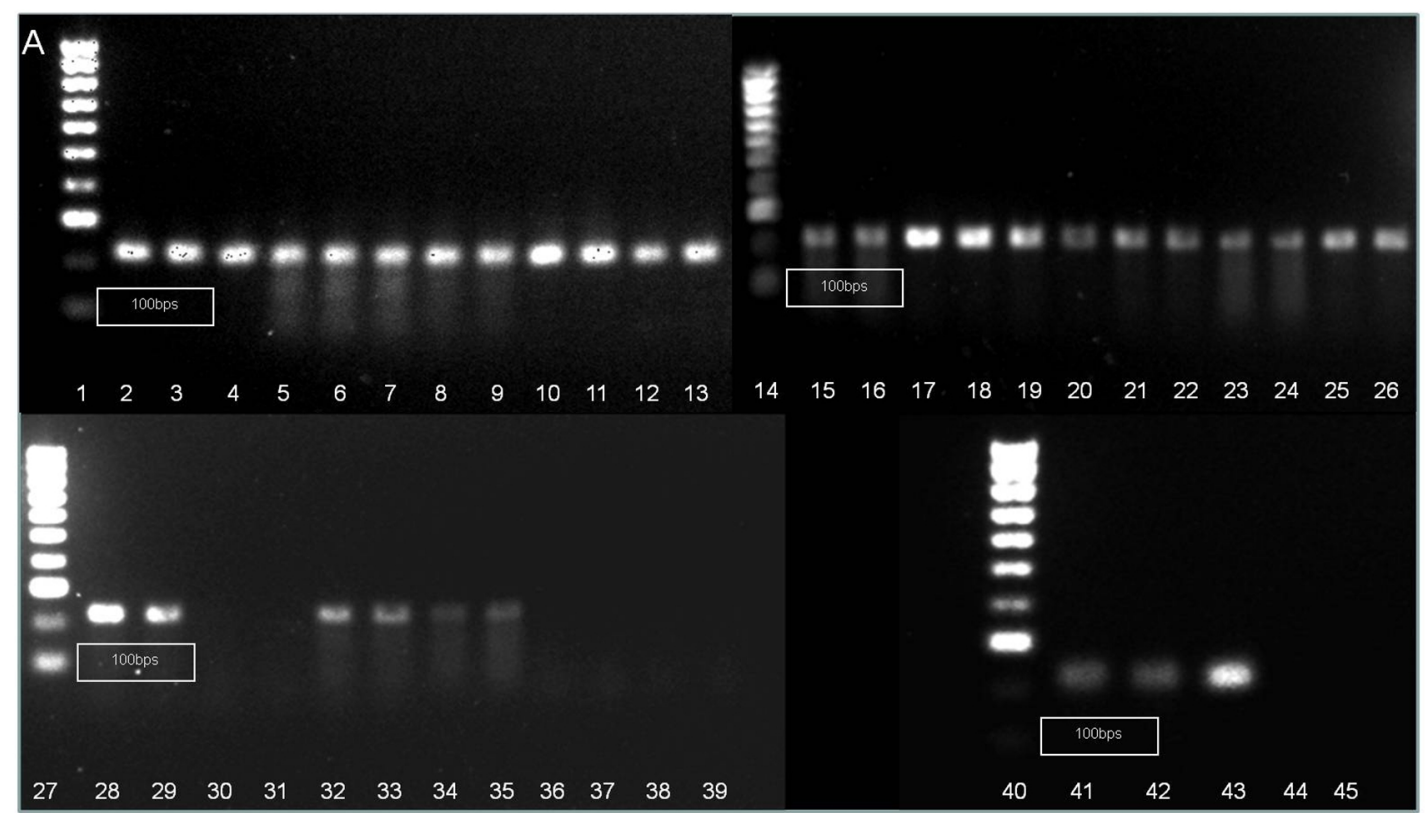

Figure 4: The relative sensitivity of nested RT-PCR in detecting GLRaV-3 in infected grapevines for comparison with ELISA and RT-LAMP. Lane 1, 14, 27, 40: Ladder (100bps); 
Lane 2-3: PL-20 1:10; Lane 4-5: 623 1:10; Lane 6-7: 621 1:10; Lane 8-9: PL-20 1:20; Lane 10-11: 623 1:20; Lane 12-13: 621 1:20; Lane 15-16: PL-20 1:30; Lane 17-18: 623 1:30; Lane 19-20: 621 1:30; Lane 21-22: PL-20 1:50; Lane 23-24: 623 1:50; Lane 25-26: 621 1:50; Lane 28-29: PL-20 1:60; Lane 30-31: 623 1:60; Lane 32-33: 621 1:60; Lane 34-35: PL-20 1:100; Lane 36-37: 623 1:100; Lane 38-39: 621 1:100; Lane 41: PL-20 (positive control); Lane 42: 623 (positive control); Lane 43: 621 (positive control); Lane 44: Healthy Control (Black Spanish); Lane 45: Negative Control (water).

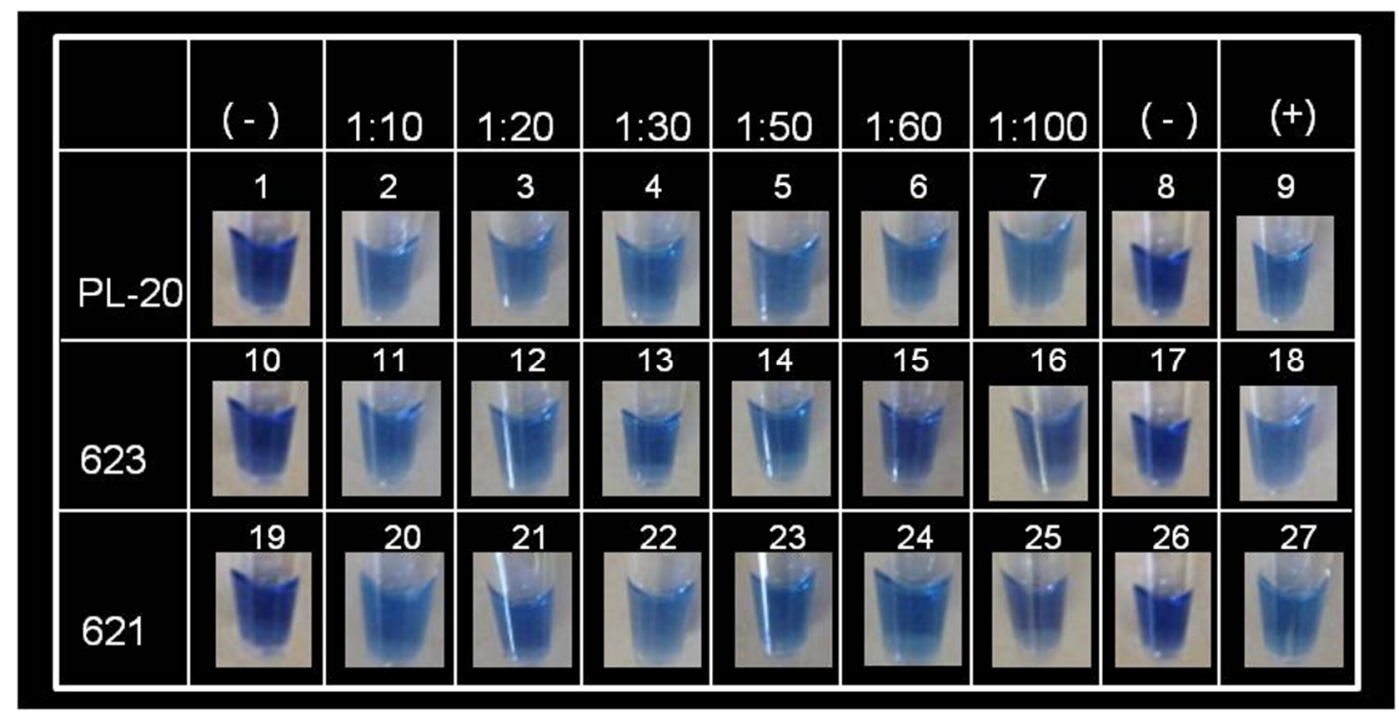

Figure 5: : The relatively sensitivity of RT-LAMP in detecting GLRaV-3 in infected grapevines for comparison with nested PCR an ELISA. (for easy of interpretation, a copy of the Black Spanish negative control has been shown included at the beginning of each dilution series and a water negative control at the end) Tube 1: Negative control (Black Spanish); Tube 2: PL20 1:10; Tube 3: PL-20 1:20; Tube 4: PL-20 1:30; Tube 5 PL-20 1:50; Tube 6 PL-20 1:60; Tube 7: PL-20 1:100; Tube 8: Negative Control (Water); Tube 9: Positive Control (PL-20); Tube 10: Negative control (Black Spanish); Tube 11: 623 1:10; Tube 12: 623 1:20; Tube 13: 623 1:30; Tube 14: 623 1:50; Tube 15: 623 1:100; Tube 16: 623 1:100; Tube 17: Negative Control (Water); Tube 18: Positive Control (623); Tube 19: Negative control (Black Spanish); Tube 20: 621 1:10; Tube 21: 621 1:20; Tube 22: 621 1:30; Tube 23: 621 1:50; Tube 24: 1:60; Tube 25: 1:100; Tube 26: Negative Control (water);Tube 27: Positive Control (621) *Only one replicate of RT-LAMP is shown

\section{Discussion}

The GLRaV-3 RT-LAMP developed here uses primers designed to detect a conserved region of the GLRaV-3 genome, to detect RNA targets extracted from GLRaV-3 infected Grapevine samples in 1 hour using only a heating block and HNB, a simple colourimetric indicator, to monitor the reaction. Additionally, a simple RNA extraction method was developed which decreases the complexity and cost of template preparation and allows for RT-LAMP to be performed in even the most basic laboratories.

Detecting GLRaV-3 has several hurdles, firstly GLRaV-3 may have a low viral titre and erratically distribution in the plant tissue and as such, diagnostics techniques do not always detect the virus satisfactorily due to low sensitivity (La Notte, 1997). Several papers have discussed the sensitivity of LAMP and advantages associated with using LAMP in situation where low titres of the target are present (Parida et al., 2008; Thai et al., 2004). The sensitivity, specificity and efficiency of LAMP are 
affected by primer concentration, the ratio of inner: outer primer, $\mathrm{Mg}^{2+}$ concentration and temperature (Nie, 2005; Notomi et al., 2000) and as such the optimisation of these reagents is vital for the detection of GLRaV-3. Sensitivity in particular was linked to the ratio of inner: outer primers with sensitivity increasing 2.5-fold where the ratio of inner: outer primer was greater than $8: 1$. Specificity and efficiency was found be highly dependent on $\mathrm{Mg}^{2+}$ concentration. $\mathrm{Mg}^{2+}$ is known to affect primer annealing (Nie 2005; Gunimaladevi et al. 2005; Teng et al. 2007; Liu et al. 2010) and it is possible that the LAMP conditions make those conditions too stringent for primers to anneal to the slight variations in sequence. RT-LAMP ideally should be able to detect all strains of the GLRaV-3 and as such it is important that the conditions not be too stringent.

The sensitivity of a detection system can be highly dependent on the manner in which the target is extracted (Osman et al. 2012). Extraction of GLRaV-3 RNA from grapevine samples is complicated by the presence of inhibitory substances in the plant which decrease detection sensitivity as well as inhibit enzymes used in RTPCR (Nakaune and Nakano, 2006). RNA extraction methods are usually either expensive, time consuming or require equipment which makes them unsuitable for use in the context of large scale testing. LAMP is a highly robust technique (Francois et al. 2011) and less likely to be affected by compounds present in grapevines. Based on this, several crude RNA extraction techniques and extraction buffers were tested for use with LAMP, with varying degrees of success. The majority of the systems tested yielded no results, while others could only detect the virus in plants where there was a high viral titre. Only one system, which combined viral immobilization on a nitrocellulose membrane with viral release using GES buffer could reliably detect the virus in all samples tested. This system is simple to use and does not require sophisticated equipment which lends it to the basic labs found on wine farms. The extraction procedure is simple and once the membranes have been dried there is little risk of contamination as the nucleic acid is bound to the membrane until released. While basic laboratory practices, such as separation of nucleic acid extraction and LAMP amplification, are necessary these practices are already followed as part of the ELISA procedure in the basic laboratories, which limits the amount of training necessary.

Pooling samples allows for a larger number of samples to be tested quickly and more cheaply (Muñoz-Zanzi et al., 2000; Wells et al.,2003; Maherchandani et al., 2004; Brinkhof et al., 2007) .However one of the greatest disadvantages of pooling samples is that it can result in a loss sensitivity of the diagnostic tests (Brinkhof et al., 2007). In the case of ELISA, the pooling of samples can also result in unacceptably high OD of samples which limits the amount of samples which can be tested together (Brinkhof et al., 2007). In the case of the ELISA currently used in the detection of GLRaV-3 in white cultivars (Pietersen and Walsh, 2012), this means that very few samples can be pooled together which increases both the cost and time needed to test a vineyard. In order for RT-LAMP to be useful in testing of grapevines for GLRaV-3 infection, its ability to detect GLRaV-3 should be comparable to molecular techniques such as nested PCR and it should be able to be used on pooled sample. 
In order to compare the relative sensitivity of RT-LAMP, ELISA and nested PCR to detect GLRaV-3 in collected GLRaV-3 samples, samples processed according to the various methods, were pooled and the end point at which a single infected individual could be detected amongst healthy individuals was determined. Results showed that nested PCR and RT-LAMP could detect a single infected plant amongst 50 healthy plants while ELISA could only detect 1 amongst 30 . The sensitivity of RT-LAMP compared to ELISA combined with the fact that the system does not require expensive equipment may contribute to the expedient screening large amounts of grapevines for GLRaV-3.

LAMP is a sensitive, reliable, robust system (Francois et al., 2011). However, in order for the system to be used effectively, there are several aspects of the test must be considered which affect the accuracy of the system. Firstly, the robustness of the system can be dependent on the indicator used. HNB was chosen as the indicator for the GLRaV-3 RT-LAMP as positive reactions are easily discernible and HNB has none of the inhibitory effects associated with other indicators (Tomlinson et al., 2010). However, several of the buffers tested for crude RNA extract protocols interfered with HNB indicator, causing false positives or inhibiting the reaction. This affects the overall robustness of LAMP and should be considered when using LAMP. Secondly, great care must be taken to separate sample preparation and the preparation of LAMP reagents as the system is highly prone to contamination and false positive reactions are difficult to ascertain.

Despite this, the relative simplicity of the reaction setup and product detection combined with its comparative sensitivity give RT-LAMP inherent advantages over ELISA and RT-PCR. The sensitivity of RT-LAMP is comparable to nested RT-PCR and greater than ELISA. Easy reaction setup and incubation make it simpler than nested PCR and the need for only basic equipment (a water bath or heating block) means it is a viable option for laboratories which do not have access to thermocyclers.

\section{Conclusion}

LAMP is a simple diagnostic technique which provides a simple way to detect GLRaV-3. With relative sensitivity comparable to nested RT-PCR assay, the onestep RT- LAMP HNB analysis exhibits potential for the detection of GLRaV-3 in both research and diagnostic labs, and offers a sensitive and efficient alternative for diagnosis of the virus that may help contribute to the eventual control of GLD, especially in symptomless white cultivars (Pietersen and Walsh, 2012).

\section{Bibliography}

Al-Musa, A., Anfoka, G., Misbeh, S., Abhary, M., Ahmad, F.H., 2008. Detection and Molecular Characterization of Squash leaf curl virus (SLCV) in Jordan. Journal of Phytopathology 156, 311-316.

Arora, S., Agarwal, R.K., Bist, B., 2006. Comparison of ELISA and PCR vis-a `-vis cultural methods for detecting Aeromonas spp . in foods of animal origin. International Journal of Food Microbiology 106, 177-183. 
Bertolini, E., Olmos, A., Martínez, M.C., Gorris, M.T., Cambra, M., 2001. Single-step multiplex RT-PCR for simultaneous and colourimetric detection of six RNA viruses in olive trees. Journal of Virological Methods 96, 33-41.

Brinkhof, J., Houwers, D., Van Maanen, C., 2007. Development of a sample pooling strategy for the serodiagnosis of small ruminant lentiviral infections using the ELITEST-MVV ELISA. Small Ruminant Research 70, 194-199.

Cabaleiro, C., Couceiro, C., Pereira, S., Cid, M., Barrasa, M., Segura, A., 2007. Spatial analysis of epidemics of Grapevine leafroll associated virus-3. European Journal of Plant Pathology 121, 121-130.

Cabaleiro, C., Segura, A., 1997. Field transmission of grapevine leafroll associated virus 3 (GLRaV-3) by the mealybug Planococcus citri. Plant Disease 81, 283-287.

Douglas, N., Krüger, K., 2008. Transmission efficiency of Grapevine leafroll-associated virus 3 (GLRaV-3) by the mealybugs Planococcus ficus and Pseudococcus longispinus (Hemiptera: Pseudococcidae). European Journal of Plant Pathology 122, 207-212.

Engel, E., Girardi, C., Escobar, P.F., Arredondo, V., Domínguez, C., Pérez-Acle, T., Valenzuela, P.D.T., 2008. Genome analysis and detection of a Chilean isolate of Grapevine leafroll associated virus-3. Virus Genes 37, 110-8.

Francois, P., Tangomo, M., Hibbs, J., Bonetti, E.-J., Boehme, C.C., Notomi, T., Perkins, M.D., Schrenzel, J., 2011. Robustness of a loop-mediated isothermal amplification reaction for diagnostic applications. FEMS Immunology and Medical Microbiology 62, $41-8$.

Fuchs, M., Marsella-Herrick, P., Loeb, G.M., Martinson, T.E., Hoch, H.C., 2009. Diversity of ampeloviruses in mealybug and soft scale vectors and in grapevine hosts from leafrollaffected vineyards. Phytopathology 99, 1177-84.

Golino, D., Sim, S., Gill, R., Rowhani, A., 2002. California mealybugs can spread grapevine leafroll disease. California Agriculture 56.

Goszczynski, D.E., Kasdorf, G.G.F., Pietersen, G., 1996. Western blots reveal that isolated grapevine virus B is serologically related to grapevine virus A. Journal of Phytopathology 144, 15-26.

Goszczynski, D.E., Kasdorf, G.G.F., Pietersen, G., 1997. Chapter 5: Production of antisera to grapevine leafroll-associated viruses using electrophoretically resolved antigens., in: Monette, P.L. (Ed) Filamentous Viruses of Woody Plants. pp. 49 - 58.

Goszczyński, D.E., Kasdorf, G.G.F;, Pietersen, G., 1995. Production and use of antisera specific to grapevine leafroll-associated virusses following electrophoretic separation of their proteins and transfer to nitrocellulose. African Plant Protection 1, 1-8.

Goto, M., Honda, E., Ogura, A., Nomoto, A., Hanaki, K.-I., 2009. Colorimetric detection of loop-mediated isothermal amplification reaction by using hydroxy naphthol blue. BioTechniques 46, 167-72. 
Gouveia, P., Santos, M.T., Eiras-Dias, J.E., Nolasco, G., 2011. Five phylogenetic groups identified in the coat protein gene of grapevine leafroll-associated virus 3 obtained from Portuguese grapevine varieties. Archives of Virology 156, 413-20.

Gunimaladevi, I., Kono, T., Lapatra, S.E., Sakai, M., 2005. A loop mediated isothermal amplification (LAMP) method for detection of infectious hematopoietic necrosis virus (IHNV) in rainbow trout (Oncorhynchus mykiss). Archives of Virology 150, 899-909.

Habili, N., Fazeli, C.F., Rezaian, M.A., 1997. Identification of a cDNA clone specific to grapevine leafroll-associated virus 1, and occurrence of the virus in Australia. Plant Pathology 46, 516-522.

Iwamoto, T., Sonobe, T., Hayashi, K., 2003. Loop-mediated isothermal amplification for direct detection of Mycobacterium tuberculosis complex, M. avium, and M. intracellulare in sputum samples. Journal of Clinical Microbiology 41, 2616.

Jooste, A.E.C., Maree, H.J., Bellstedt, D.U., Goszczynski, D.E., Pietersen, G., Burger, J .T., 2010. Three genetic grapevine leafroll-associated virus 3 variants identified from South African vineyards show high variability in their 5'UTR. Archives of Virology 155, 1997-2006.

Jooste, A.E.C., Pietersen, G., Burger, J.T., 2011. Distribution of grapevine leafroll associated virus-3 variants in South African vineyards. European Journal of Plant Pathology 131, $371-381$.

Krake, L., Scott, N., Rezaian, M., Taylor, R., 1999. Graft-transmitted diseases of grapevines, illustrate. ed. CSIRO PUBLISHING.

La Notte, P., 1997. A spot-PCR technique for the detection of phloem-limited grapevine viruses. Journal of Virological Methods 66, 103-108.

Ling, K., Zhu, H., Jiang, Z., Gonsalves, Dennis, 2000. Effective application of DAS-ELISA for detection of grapevine leafroll associated closterovirus-3 using a polyclonal antiserum developed from recombinant coat protein. European Journal of Plant Pathology 106, 301-309.

Ling, K.-S., Zhu, H., Drong, R., Slightom, J., McFerson, J., Gonsalves, Dennis, 1998. Nucleotide sequence of the 3'-terminal two-thirds of the grapevine leafroll-associated virus-3 genome reveals a typical monopartite closterovirus. Journal of General Virology $79,1299$.

Ling, K.-S., Zhu, H.-Y., Petrovic, N., Gonsalves, Dennis, 2001. Comparative Effectiveness of ELISA and RT-PCR for Detecting Grapevine Leafroll-Associated Closterovirus-3 in Field Samples. American Journal of Enology and Viticulture 52, 21-27.

Liu, Y., Wang, Z., Qian, Y., Mu, J., Shen, L., Wang, F., Yang, J., 2010. Rapid detection of tobacco mosaic virus using the reverse transcription loop-mediated isothermal amplification method. Archives of Virology 155, 1681-5. 
Maeda, H., Kokeguchi, S., Fujimoto, C., Tanimoto, I., Yoshizumi, W., Nishimura, F., Takashiba, S., 2005. Detection of periodontal pathogen Porphyromonas gingivalis by loop-mediated isothermal amplification method. FEMS Immunology and Medical Microbiology 43, 233-9.

Maherchandani, S., Muñoz-Zanzi, C.A., Patnayak, D.P., Malik, Y.S., Goyal, S.M., 2004. The Effect of Pooling Sera on the Detection of Avian Pneumovirus Antibodies using an Enzyme-Linked Immunosorbent Assay Test. Journal of Veterinary Diagnostic Investigation 16, 497.

Maree, H.J., Freeborough, M.J., Burger, J.T, 2008. Complete nucleotide sequence of a South African isolate of grapevine leafroll-associated virus 3 reveals a 5'UTR of 737 nucleotides. Archives of Virology 153, 755-7.

Martelli, G.P., 1993. Graft-transmissible diseases of grapevines: handbook for detection and diagnosis. Food \& Agriculture Org., Rome, Italy.

Martelli, G.P., Abou Ghanem-Sabanadzovic, N., Agranovsky, A.A., Al Rwahnih, M., Dolja, V.V., Dovas, C.I., Fuchs, M., Gugerli, P., Hu, J.S., Jelkmann, W., Katis, N.I., Maliogka, V.I., Melzer, M.J., Menzel, W., Minafra, A., Rott, M.E., Rowhani, A., Sabanadzovic, S., Saldarelli, P., 2012. Taxonomic revision of the family Closteroviridae with special reference to the grapevine leafroll-associated members of the genus Ampelovirus and the putative species unassigned to the family. Journal of Plant Pathology 94, 7-19.

Martelli, G.P., Agranovsky, A.A., Bar-Joseph, M., Boscia, D., Candresse, T., Coutts, R., Dolja, V., Falk, BW, Gonsalves, D, Jelkmann, W., Karasev, A., Minafra, A., Namba, S., Vetten, H.., Wisler, G.., Yoshikawa, N., 2002. The family Closteroviridae revised. Archives of Virology 147, 2039-2044.

Mori, Y., Nagamine, K., Tomita, N., Notomi, T., 2001. Detection of loop-mediated isothermal amplification reaction by turbidity derived from magnesium pyrophosphate formation. Biochemical and Biophysical Research Communications 289, 150-4.

Muñoz-Zanzi, C.A., Johnson, W.O., Thurmond, M.C., Hietala, S.K., 2000. Pooled-sample testing as a herd-screening tool for detection of bovine viral diarrhea virus persistently infected cattle. Journal of Veterinary Diagnostic Investigation 12, 195.

Nakaune, R., Nakano, M., 2006. Efficient methods for sample processing and cDNA synthesis by RT-PCR for the detection of grapevine viruses and viroids. Journal of Virological Methods 134, 244-9.

Nie, X., 2005. Reverse transcription loop-mediated isothermal amplification of DNA for detection of Potato virus Y. Plant Disease 89, 605-610.

Notomi, T., Okayama, H., Masubuchi, H., Yonekawa, T., Watanabe, K., Amino, N., Hase, T., 2000. Loop-mediated isothermal amplification of DNA. Nucleic Acids Research 28, e63. 
Osman, F., Olineka, T., Hodzic, E., Golino, D.A., Rowhani, A., 2012. Comparative procedures for sample processing and quantitative PCR detection of grapevine viruses. Journal of Virological Methods 179, 303-10.

Osman, F., Rowhani, A., 2006. Application of a spotting sample preparation technique for the detection of pathogens in woody plants by RT-PCR and real-time PCR (TaqMan). Journal of virological methods 133, 130-6.

Over de Linden, A., Chamberlain, E., 1970. Effect of grapevine leafroll virus on vine growth and fruit yield and quality. New Zealand Journal of Agricultural Research 37-41.

Parida, M., Sannarangaiah, S., Dash, P.K., Rao, P.V.L., Morita, K., 2008. Loop mediated isothermal amplification (LAMP): a new generation of innovative gene amplification technique; perspectives in clinical diagnosis of infectious diseases. Reviews in Medical Virology 18, 407-421.

Pietersen, G., 2004. Spread of grapevine leafroll disease in South Africa-a difficult but not insurmountable problem [WWW Document]. Technical Yearbook 2004/5. URL http://www.wynboer.co.za/recentarticles/0406leaf.php3 (accessed 1.18.13).

Pietersen, G., Spreeth, N., Oosthuizen, T., Rensburg, A. van, Rensburg, M. van, Lottering, D., Rossouw, N., Tooth, D., 2013. Control of Grapevine Leafroll Disease Spread at a Commercial Wine Estate in South Africa: A Case Study. American Journal of Enology and Viticulture February.

Pietersen, G., Walsh, H.A., 2012. Development of a LAMP Technique for Control of Grapevine Leafroll Associated Virus Type 3 (GLRaV-3) in Infected White Cultivar Vines by Roguing, in: Extended Abstracts of 17th Congress of the International Council for the Study of Virus and Virus-like Diseases of the Grapevine (ICVG), Davis, California, USA, October 7-14th. pp. 50-51.

Rowhani, A., Chay, C., Golino, D.A., Falk, B., 1993. Development of a polymerase technique for the detection of grapevine fanleaf virus in grapevine tissue. Phytopathology 83, 749-753.

Singh, R.P., Dilworth, A.D., Singh, M., Babcock, K.M., 2006. An alkaline solution simplifies nucleic acid preparation for RT-PCR and infectivity assays of viroids from crude sap and spotted membrane. Journal of Virological Methods 132, 204-11.

Teng, P.H., Chen, C.L., Sung, P.F., Lee, F.C., Ou, B.R., Lee, P.Y., 2007. Specific detection of reverse transcription-loop-mediated isothermal amplification amplicons for Taura syndrome virus by colorimetric dot-blot hybridization. Journal of Virological Methods $146,317-326$.

Thai, H.T.C., Le, M.Q., Vuong, C.D., Parida, Manmohan, Minekawa, H., Notomi, T., Hasebe, F., Morita, K., 2004. Development and evaluation of a novel loop-mediated isothermal amplification method for rapid detection of severe acute respiratory syndrome coronavirus. Journal of Clinical Microbiology 42, 1956. 
Tomlinson, J. a., Boonham, N., Dickinson, M., 2010. Development and evaluation of a onehour DNA extraction and loop-mediated isothermal amplification assay for rapid detection of phytoplasmas. Plant Pathology 59, 465-471.

Turturo, C., Minafra, A., Ni, H., Wang, G., Di Terlizzi, B., Savino, V., 1998. Occurrence of peach latent mosaic viroid in China and development of an improved detection method. Journal of Plant Pathology 80, 165-169.

Turturo, C., Saldarelli, P., Yafeng, D., Digiaro, M., Minafra, A., Savino, V., Martelli, G.P., 2005. Genetic variability and population structure of Grapevine leafroll-associated virus 3 isolates. Journal of General Virology 86, $217-224$.

Walton, V., 2004. Vine mealybug, Planococcus ficus (Signoret)(Hemiptera: Pseudococcidae), a key pest in South African vineyards. A review. South African Journal of Enology and Viriculture 25, 54-62.

Wells, S., Godden, S., Lindeman, C., Collins, J.E., 2003. Evaluation of bacteriologic culture of individual and pooled fecal samples for detection of Mycobacterium paratuberculosis in dairy cattle herds. Journal of the American Veterinary Medical Association 223, $1022-1025$. 